\title{
"Mal de cintura" disorder characterization of pineapple MD2 in agroclimatic conditions of flat area of Valle del Cauca, Colombia
}

\section{Caracterización del "mal de cintura" de la piña MD2 en condiciones agroclimáticas de la zona plana del Valle del Cauca, Colombia}
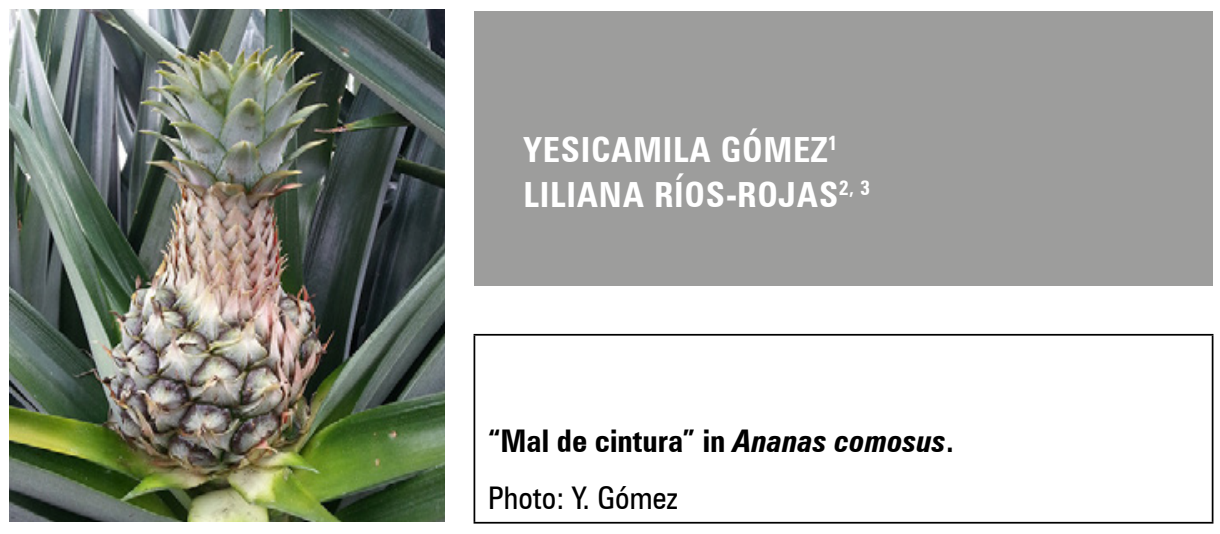

\begin{abstract}
In some localities in Colombia a physiological disorder called "Mal de cintura", is present in MD2 pineapple productive farms. It is a deformation of the fruit due to the incomplete development of contiguous flowers that produces a physical damage (external appearance); generating fruit rejection in the market. Factors that trigger this problem are unknown. This research was carried out on two farms in Valle del Cauca, Colombia, soil moisture and ambient temperature conditions were evaluated on the expression of the physiological disorder. In farm 1, vegetative and productive phases of the crop were evaluated. The results indicate that the plants were not in water deficit before, during or after flowering, ruling out this factor on the expression of the physiological disorder. During flowering, maximum temperatures reached $35^{\circ} \mathrm{C}$ and minimum temperatures $18^{\circ} \mathrm{C}$ were recorded, giving an alert on this variable due to the presence of the physiological disorder of $96 \%$ of the crop. In farm 2, a more detailed monitoring of the temperatures was carried out during the inflorescence development. In this period, maximum temperature inside crop was $58.5^{\circ} \mathrm{C}$ and the minimum was $15.5^{\circ} \mathrm{C}$, symptoms of deformation were present in $78 \%$ of the crop. Results were inconclusive about temperature influence on fruit deformation. A chemical analysis of inflorescences tissue with and without expression of the physiological disorder was performed to validate the influence of a nutritional problem. Results indicated that damaged inflorescences had higher copper, zinc and manganese contents than healthy inflorescences.
\end{abstract}

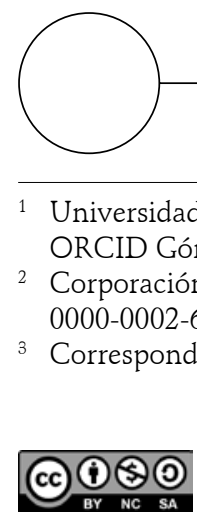

Additional key words: Ananas comosus L. Merr.; physiological disorder; flowering; soil moisture; nutrition; temperature.

\footnotetext{
Universidad Nacional de Colombia, Sede Palmira, Departamento de Ciencias Agropecuarias, Palmira (Colombia). ORCID Gómez, Y.: 0000-0002-2835-4025

Corporación Colombiana de Investigación Agropecuaria - Agrosavia, Palmira (Colombia). ORCID Ríos-Rojas, L.: 0000-0002-6978-0434

Corresponding author. Iriosr@agrosavia.co
} 


\section{RESUMEN}

En algunas localidades productoras de piña MD2 en Colombia, se presenta un desorden fisiológico llamado "Mal de cintura". Es una deformación del fruto debido a la ausencia de flores contiguas que produce daño físico, lo que resulta en el rechazo de la fruta. Los factores que mejoran esta fisiopatología son desconocidos. Esta investigación, realizada en dos fincas en el Valle del Cauca, Colombia, evaluó las condiciones de humedad del suelo y temperatura ambiente en la expresión de la fisiopatología. En la finca 1, se evaluaron las fases vegetativa y productiva del cultivo. Los resultados indican que las plantas no tuvieron déficit de agua antes, durante y después de la floración, descartando este factor en la expresión de la fisiopatología. Durante la floración, se registraron temperaturas máximas de $35^{\circ} \mathrm{C}$ y temperaturas mínimas de $18^{\circ} \mathrm{C}$, dando una alerta sobre esta variable debido a la presencia del trastorno fisiológico del $96 \%$ del cultivo. En la finca 2 , se realizó un monitoreo más detallado de la temperatura durante la formación de la inflorescencia. En este período, la temperatura máxima dentro del cultivo fue de $58,5^{\circ} \mathrm{C}$ y la mínima de $15,5^{\circ} \mathrm{C}$, observando síntomas de deformación en el $78 \%$ del cultivo. No fue posible concluir acerca de la influencia de la temperatura sobre la deformación de la fruta. Se realizó un análisis químico del tejido de inflorescencias con y sin expresión de la fisiopatía para validar la influencia de un problema nutricional. Los resultados indican que las inflorescencias con el trastorno fisiológico tienen un mayor contenido de cobre, zinc y manganeso que las inflorescencias sin el trastorno.

Palabras clave adicionales: Ananas comosus L. Merr.; fisiopatía; floración; humedad del suelo; nutrición; temperatura.

Received for publication: 10-03-2020 Accepted for publication: 11-06-2020
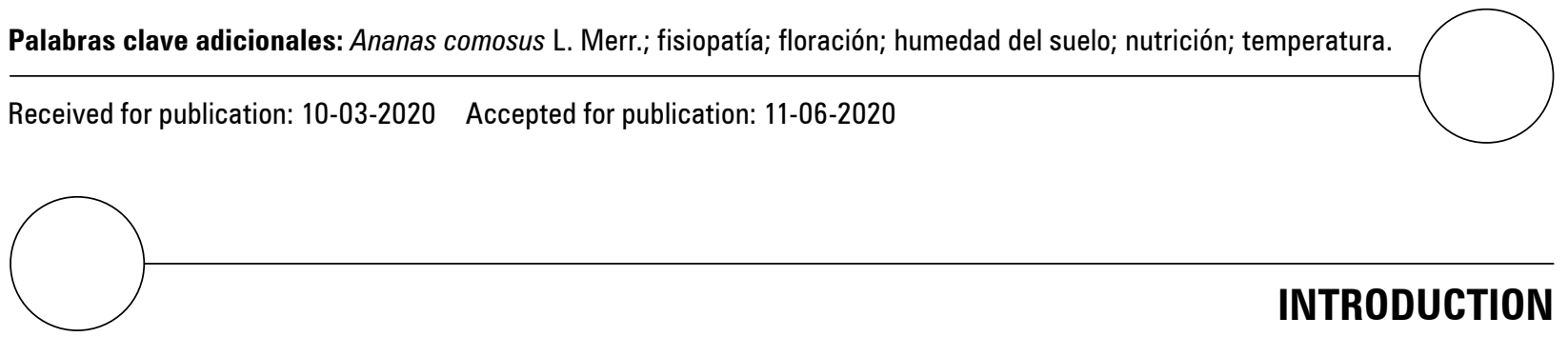

INTRODUCTION

Pineapple (Ananas comosus L. Merr.) belongs to the Bromeliaceae family, it has a CAM (crassulacean acid metabolism) photosynthetic adaptation, a condition that facilitates the uptake of carbon dioxide $\left(\mathrm{CO}_{2}\right)$ whit stomatal aperture at night. This metabolism permits the closure of the stomata in daylight condition, generating almost complete, cessation of transpiration (Bartholomew and Kadzimin, 1977), this allows pineapple to have a high water-use efficiency in dry environments (Carr, 2012). Pineapple plant is herbaceous, with a stem in which a spiral of rigid leaves grows, vegetative growth stops when lowering time comes. The reproductive phase starts with the inflorescence expression, producing around of 150-200 flowers, they will turn into a parthenocarpic fruit that develops from the bract, the sepals, and the ovary; since the stamens, style and petals wilt and fall after anthesis (Vásquez et al., 2012). On the top of the fruit a set of leaves is formed which is known as a crown. Under normal conditions, only a spiral of small leaves is observed. Below the fruit, on the sides of the stem and the underground root, suckers are observed; they will generate new plants and fruits. The plant develops an extensive underground and axillary root system. These axillary or aerial roots wrap around the stem, where they absorb water and nutrients funneled by leaves (Crane, 2019). Pineapple crop is tolerant to dry weather conditions; however, in absence of complementary water supply plant growth and fruit production is reduced (Crane, 2019).

In addition to pest and disease problems, pineapple cultivation has several physiological problems. Even when this crop is the second most desired fruit worldwide, physiological problems of the species have been poorly studied. Disorders as premature (natural) flowering that affects the uniformity of production, multiple crowns, and fruit deformity, all of which impair the external quality of the product. Although these problems do not alter the organoleptic quality of the fruit, consumers reject them as the fruits do not present commercial shape and color standards.

Commercial Quality Standard for freshly consumed pineapple (CODEX STAN 182-1993) was adopted in 1993, revised in 1999, and amended in 2011 (Codex Alimentarius, 2011). This document defines the parameters for a good fruit quality and indicates that fresh pineapples should be whole and either with or without the crown. Fruit must be healthy, clean, free of abnormal external moisture or rot; no insects must be present, any visible foreign matter, free of any 
smell off-taste; and it must have a fresh appearance. Crowns must be free of dead or dry leaves. Regarding fruit maturity, the minimum total soluble solids content of the fruit pulp should be $12^{\circ} \mathrm{Brix}$. Weight is the most important parameter for quality classification. In this sense, category " $\mathrm{A}$ " refers to fruits of $2,750 \mathrm{~g}$ with a crown and 2,280 $\mathrm{g}$ without a crown. The fruit quality factors that may cause export rejection, include physical problems such as fruit malformations like what is known as mal de cintura in Spanish. Nevertheless, in some markets, a slight fruit deformation is accepted (Cabal, 2014).

Mal de cintura is a physiological disorder which spoils the physical quality of pineapple fruit, but not its pulp quality. This problem affects market quality, leading to reduced acceptance of the product by consumers (Cabal, 2014). This physiological disorder is caused by the malformation of flowers and consequent failure to form some individual fruits. Up to $29 \%$ of MD2 pineapple the production has been reported as lost due to this physiological disorder on a farm in the department of Valle del Cauca (Luis Miguel Cabal, producer, personal communication). No published reports of this disorder exists; however, it is believed to be a physiological disorder since the problem is generally present in fields without associated pathogens and is only found in a few farms within the flat area of Valle del Cauca department, Colombia.

A physiological disorder is described as a type of external damage that appears in the plant and is caused by abiotic factors (Kennelly et al., 2012). Abiotic disorders are associated with climate, soils, chemical products, mechanical injuries, cultural practices, and in some cases, to plant genetic predisposition (Kennelly et al., 2012). Physiological disorders can be caused by chronic conditions, such as prolonged drought or a selection of inappropriate plants for environmental conditions of the cultivation site. The lesion or symptom, such as reduced growth or death, is ultimately due to the cumulative effects of the causal factors in physiological processes necessary for plant growth and development (Kennelly et al., 2012).

In this study, inflorescence formation was followed in detail to characterize development of MD2 pineapple deform fruits, focusing on humidity and soil temperature effects, previous research had shown that water stress and severe temperatures affect the flowering process (Wang et al., 2018; Hedhly, 2011). Temperature monitoring was done, verifying high temperatures occurrence and its relationship with this physiological disorder appearance as first approach. Healthy and affected meristematic tissues were studied to asses' nutritional deficiencies that would contribute to the characterization of the problem. Further studies should be done in gene expression during flower development to understand what is occurring internally.

\section{MATERIALS AND METHODS}

\section{Study zone}

This research was carried out on two agricultural farms in Guadalajara de Buga, department of Valle del Cauca (Colombia). Farm 1 was located at the geographical coordinates $03^{\circ} 51^{\prime} 52.56^{\prime \prime} \mathrm{N}$ and $76^{\circ} 18^{\prime} 00.87^{\prime \prime} \mathrm{W}$, at an altitude of $974 \mathrm{~m}$ a.s.l., with an annual rainfall of $1,168 \mathrm{~mm}$ and an average annual temperature of $23.6^{\circ} \mathrm{C}$. Farm 2 was located at the geographical coordinates $03^{\circ} 54^{\prime} 08.40^{\prime \prime} \mathrm{N}$ and $76^{\circ} 18^{\prime} 55.55^{\prime \prime} \mathrm{W}$, at an altitude of $953 \mathrm{~m}$ a.s.l., with an annual rainfall of $1,120 \mathrm{~mm}$ and an average annual temperature of $24.1^{\circ} \mathrm{C}$.

\section{Pineapple production system}

Selected farms had a planting density of 62,000 MD2 hybrid plants per hectare in a double row planting system with a distance between plants of $23 \mathrm{~cm}$, and $50 \mathrm{~cm}$ between rows. Beds (2 rows) had 25 to 30 $\mathrm{cm}$ height, $70 \mathrm{~cm}$ width $100 \mathrm{~m}$ length; thirteen beds composed one block. On farm 1 soil moisture was monitored with a humidity sensor. For daily maximum and minimum temperature ambient a mercury thermometer was used. Experimental section corresponded to three contiguous pineapple blocks (Tab. 1). Experiments were established when seeds were sowed, and measurements were made accordingly to the number of days since sowing (DAS). Second temperature assessment was carried out on farm 2, where a block with 12.000 plants in a phase previous and near to flowering was selected. This crop has been characterized by an asynchronous flowering, which has generated high economic costs in agronomic management and harvesting, for this reason, it has been necessary to use hormonal regulators to force flowering and have a uniform management and harvest. Flowering inductors are applied when the plant reaches a weight of $3.5 \mathrm{~kg}$. This weight is determined by destructive sampling during the vegetative 
stage. Farmers standardized formula for flower induction is $1.2 \mathrm{~L}$ Ethrel ${ }^{\circledR}, 60 \mathrm{~kg}$ urea and $5.4 \mathrm{~kg}$ boron for hectare of pineapple crop. Foliar applications of this solution are done in the afternoon; when plants open their stomata. In farm 1 induction application of first block was carried out at 307 DAS (December 16, 2017); second and third blocks' application was done at 325 DAS (December 23, 2017). A high frequency irrigation system was installed (drip), with an 8,000-gauge tape and with $1 \mathrm{~L} \mathrm{~h}^{-1}$ emitter spaced every $20 \mathrm{~cm}$. During the experimental period, no irrigation was applied.

\section{Table 1. Blocks characteristics on farm 1.}

\begin{tabular}{|c|c|c|c|}
\hline Block & $\begin{array}{c}\text { Number of } \\
\text { plants }\end{array}$ & $\begin{array}{c}\text { Beginning of the } \\
\text { evaluation (DAS) }\end{array}$ & $\begin{array}{c}\text { Age of induction } \\
\text { (DAS) }\end{array}$ \\
\hline 1 & 9,968 & 250 & 307 \\
\hline 2 & 10,313 & 250 & 325 \\
\hline 3 & 9,989 & 232 & 325 \\
\hline
\end{tabular}

DAS: days after sowing.

\section{Edaphic characterization}

Both farms are in the flat area of the department. Physical characterization of the soil considered first $30 \mathrm{~cm}$ where most roots are found. With the help of rings for unaltered soil samples, 6 samples were taken for the determination of apparent density and moisture retention curve on each farm. For texture and actual density analysis, four random sub samples were collected and mixed as they did not present visual differences in color, humidity, structure and texture. These soil samples were taken to the soil laboratory National University of Colombia, Palmira Campus. For the chemical analysis, a grand soil sample was consolidated with subsamples taken at different points of the fields before planting. This sample was analyzed in the laboratory of the Providencia sugarcane mill in Palmira, department of Valle del Cauca.

\section{Soil moisture monitoring}

Field capacity (FC) and permanent wilting point (PWP) of soil was established based on the moisture retention curve (MRC) of farm 1, where the soil moisture content was assessed. This evaluation was recorded from October 19, 2016, until May 25, 2017; this period includes the end of the vegetative stage and the entire productive stage.
For monitoring the soil moisture content, a capacitance-type moisture sensor $\mathrm{ECH}_{2} \mathrm{O}$ reference EC- 5 accuracy $\pm 3 \%$ was installed in each selected batch at a depth of $25 \mathrm{~cm}$; at this depth, the highest percent of pineapple roots is found (Maia et al., 2020). Sensor registered the moisture content each $30 \mathrm{~min}$ and data were saved in a Datalogger. Data analysis allowed to verify that during the period evaluated, plants did not undergo a drought stress condition. Each week, humidity sensors were calibrated to verify results reliability. With the help of a drill pipe, soil samples were taken from the beds where the sensors were located, and moisture tests were carried out using the gravimetric method.

\section{Environmental temperature monitoring}

Temperature monitoring was carried out for two periods. The first period evaluated at Farm 1 began on February 13, 2016 (planting) until May 18, 2017 (harvest). This monitoring was done to know the dynamics of maximum daytime and minimum nighttime temperatures throughout the crop cycle. Data recording was made daily with a mercury thermometer Brixco brand accuracy $\pm 2^{\circ} \mathrm{C}$ located in the experimental area at a height of $2 \mathrm{~m}$ above the ground and in direct sunlight

Second monitoring period was carried out on farm 2 between August 12 and September 10, 2017. Temperature measuring was maintained for 4 weeks after flower induction, since it was possible at this time to visualize the flowers formed. Temperature throughout the day was measured with a digital thermometer at a frequency of $5 \mathrm{~min}$ and it was installed in the center of the experimental batch $1 \mathrm{~m}$ high above ground level in order to record the temperature closest to the space where the inflorescence. Calibration of the digital thermometer was performed daily with a mercury thermometer located at the same position.

\section{Physiological disorder monitoring}

Two hundred sixty-seven plants were randomly selected per block. Expression of the physiological disorder was followed in the flowering and fruit growth stages. In farm 2 where the second environmental temperature assessment was carried out, the expression of the physiological disorder was tracked from 60 days after induction (DDI) of fruit. Five points from the growing lot were randomly selected, in which 
100 plants per point were chosen for a total of 500 plants evaluated. It was guaranteed that the selected plants were found in the same flower development, therefore all inflorescences of the plants had equal amounts of flowers. The physical disease was tracked until 150 DDI, where the presence of the fruit deformation was verified due to flowers malformations.

\section{Floral primordia evaluation}

To study flower development, inflorescences were collected on farm 2 from the $1^{\text {st }}$ week after induction (WAI) to the $4^{\text {th }}$. When floral tissues were extracted, some stem leaves had to be extracted to expose its peduncle. This sampling was done randomly in the experimental batch by collecting 20 floral buttons per week. Collected inflorescences were taken to the Botany laboratory of the National University of Colombia, Palmira headquarters, to be observed in stereoscope, flower external structure and morphological changes during the formation of the inflorescence were observed by this means.

In the laboratory, inflorescences were washed to avoid unwanted material and the bracts of each flower were removed to improve floral meristem display and check the presence of deformation. Subsequently, inflorescences were classified in into two groups, one with physiological disorder (absence of any individual floral structure) and another with healthy (formation of all the flowers) flowers. Both samples were sent to the Agrosavia laboratory in Mosquera (Cundinamarca) to perform a complete nutrient analysis and verify if there was a difference between the chemical contents of the button tissue (healthy and physiological disorder) and to establish its relationship with soil nutritional content.

\section{Experimental design}

Farm 1 evaluation initially sought to evaluate the effect of soil moisture on the expression of physiological disorder, installing three moisture content on the ground with a control under a completely randomized block design with three replications. However, frequent rainfall during the experimental period retained soil moisture content higher than field capacity, preventing treatments from being applied. For this reason, the experiment was based on observation method and assessed the presence or absence of the physiological disorder based on soil humidity and ambient temperature.

\section{RESULTS AND DISCUSSION}

\section{Edaphic characterization}

In farm 1 , the FC of the soil was $28.9 \%$, and the PWP was $15.6 \%$; texture was classified as clay at the two depths sampled; apparent density was $1.29 \mathrm{~g} \mathrm{~cm}^{-3}$ at $10 \mathrm{~cm}$ of depth and $1.31 \mathrm{~g} \mathrm{~cm}^{-3}$ at $20 \mathrm{~cm}$ of depth. According to the USDA (1999), a soil with clay texture would have an apparent density of less than $1.1 \mathrm{~g} \mathrm{~cm}^{-3}$, which will allow a good radical growth; furthermore, if it is above $1.39 \mathrm{~g} \mathrm{~cm}^{-3}$, it could cause root damage. As can be seen, the apparent density of the experimental site is above $1.1 \mathrm{~g} \mathrm{~cm}^{-3}$ however, the roots were observed as healthy and with adequate development.

Soil $\mathrm{pH}$ of the farm tended to be neutral, with a value of 6.5. Electrical conductivity was $0.49 \mathrm{dS} \mathrm{m}^{-1}$, nonsaline soil. Organic matter content was low, with a value of $1.51 \%$ (Tab. 2). Phosphorus, calcium, magnesium and potassium contents were high. Calcium/ magnesium and calcium/potassium ratios showed normal levels, indicating no problem of availability of these bases. In general, in farm 1, there were no problems with the nutritional content of the soil for the cultivation of pineapple.

Farm 2 soil was a sandy clay franc, with an apparent density of $1.57 \mathrm{~g} \mathrm{~cm}^{-3}$. Nutrient content (Tab. 2) indicated that soil was deficient in boron, phosphorus, sulfur and nitrogen. Deficiencies were corrected with fertilization. The soil was high in calcium, iron and copper; the other elements showed optimal ranges. However, as there was a high calcium content, magnesium and potassium applications were to enhance an interchangeable base ratios.

\section{Climatic characterization}

Figure 1 shows precipitation records during the experimental period on farm 1 . The first rainy season for farm 1 occurred from October 25, 2016, to January 21, 2017 (Fig. 1). The final part of the vegetative and flowering stages showed a cumulative precipitation of $433 \mathrm{~mm}$. Subsequently, there was a dry period in the $1^{\text {st }} \mathrm{d}$ of fruit filling, from January 22, 2017, to March 1, 2017, with an accumulated precipitation of $29 \mathrm{~mm}$, followed by a rainy period until harvest (May 17, 2017), with a cumulative precipitation value of $477 \mathrm{~mm}$. 
Table 2. Chemical content of the soil of farms 1 and 2.

\begin{tabular}{|c|c|c|c|c|}
\hline \multicolumn{2}{|c|}{ Factor } & Analytical method & Farm 1 & Farm 2 \\
\hline \multicolumn{2}{|l|}{$\mathrm{pH}[\mathrm{V}: \mathrm{V}, 1: 1]$} & Potentiometric & 6.5 & 5.36 \\
\hline \multicolumn{2}{|c|}{ Electrical conductivity $\left(\mathrm{dS} \mathrm{m}^{-1}\right.$ ) } & Conductimeter & 0.49 & 0.64 \\
\hline \multicolumn{2}{|c|}{ Organic matter (\%) [Walkley-Black] } & Calculation & 1.51 & 1.1 \\
\hline \multicolumn{2}{|c|}{ Phosphorous (mg kg-1) [Bray II] } & Colorimetric & 41.10 & 0.78 \\
\hline \multicolumn{2}{|l|}{ Calcium $\left(\mathrm{cmol} \mathrm{kg}^{-1}\right)$} & Atomic absorption & 10.58 & 13.2 \\
\hline \multicolumn{2}{|l|}{ Magnesium $\left(\mathrm{cmol} \mathrm{kg}^{-1}\right)$} & Atomic absorption & 6.98 & 4.7 \\
\hline \multicolumn{2}{|l|}{ Potassium $\left(\mathrm{cmol} \mathrm{kg}^{-1}\right)$} & Atomic absorption & 1.63 & 0.48 \\
\hline \multicolumn{2}{|l|}{ Sodium $\left(\mathrm{cmol} \mathrm{kg}^{-1}\right)$} & Atomic absorption & 0.19 & 0.37 \\
\hline \multicolumn{2}{|c|}{ Cation exchange capacity $\left(\mathrm{cmol} \mathrm{kg}^{-1}\right)$} & Calculation & 16.87 & 18.9 \\
\hline \multicolumn{2}{|l|}{$\mathrm{Ca} / \mathrm{Mg}$ ratio } & Calculation & 1.52 & 2.82 \\
\hline \multicolumn{2}{|l|}{$\mathrm{Ca} / \mathrm{K}$ ratio } & Calculation & 6.49 & 27.6 \\
\hline \multirow{4}{*}{ Base saturation (\%) } & $\mathrm{Ca}$ & Calculation & 54.59 & 70.0 \\
\hline & $\mathrm{Mg}$ & Calculation & 36.02 & 24.8 \\
\hline & $\mathrm{K}$ & Calculation & 8.41 & 2.54 \\
\hline & $\mathrm{Na}$ & Calculation & 0.98 & 1.95 \\
\hline
\end{tabular}

Given the soil characteristics, i.e., with poor drainage due to the high clay content and the contribution of precipitation, the moisture content was maintained over the field capacity throughout the experimental period (Fig. 1). The maximum soil moisture content was $51.8 \%$ and the minimum content was $30.7 \%$, both greater than the field capacity (28.9\%). These conditions guaranteed that the crop did not suffer stress due to soil water deficit during the experimental period, especially in the flowering stage (Fig. 1).
Given the behavior of moisture content in the crop, it was not necessary to apply irrigation during the experimental period. Thus, this work initially proposed as experimental to evaluate the expression of physiological disorder based on different levels of irrigation became an observational rigor investigation. The first hypothesis of this work concerned the adverse effect that soil water deficit could have on flower formation and subsequent filling of the fruit; progressing research shows that soil water content is

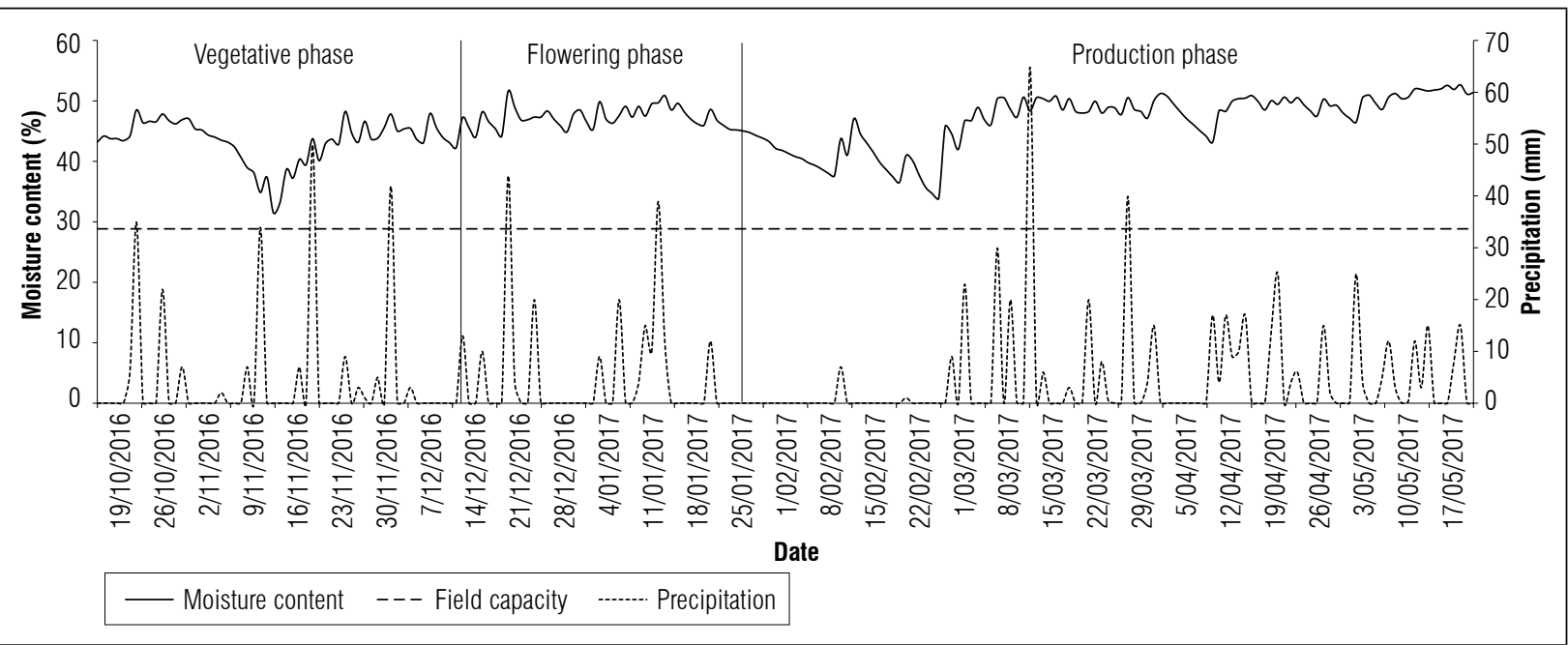

Figure 1. Soil moisture content and precipitation during the experimental period on farm 1. 
not a limiting factor; however, physiological disorder is expressed.

While monitoring the development of flowers and fruits, it was observed that the starting point of this deformation was the "absence" of some adjoining individual flowers, that is, they never managed to become an individual fruit, these "empty" spaces are the ones that gave rise to the deformation in a section of fruit commonly called "cintura" (waist). Plants were checked for excess moisture in how it could affect plant growth. Roots were firm, white, no rot signs were seeing, leaves were thick and turgid. Delay or damage on the vegetative growth of the plant was not observed due to possible anoxic condition, this is due to the presence of adventitious roots, which are fully functional in the genus Ananas. A plant with different anatomical and functional structures would have become ill and dye when facing this kind of water excess. At this point the effect of soil moisture content is discarded and the monitoring focused on temperature and its effect on flower formation.

Other types of stress on the plants evaluated were ruled out, such as attack or establishment of pests or diseases, since foliage and root were always in an adequate health condition. At the end of the productive stage there was an attack of Thielaviopsis paradoxa (De Seynes) Höhn; disease that affects ripe fruits and manages to penetrate by mechanical wounds in the plant. At this point, fruits were already formed and physiological disorder was already present, which is why its effect on deformation is ruled out. The effect of nutrition was not ruled out. A comparison of the nutritional contents of the soil and the meristematic tissue of floral buttons was executed.

\section{Inflorescence and fruit development monitoring}

The first sighting of inflorescences in the culture occurred 45 days after induction (DAI). Figure 2A shows flower buds (first stage of the inflorescence, Fig. 2A) in most of the selected plants. Buds were characterized by the presence of pink bracts that are located on the periphery, white bracts towards the center; less developed than the pink ones. Bracts turn white to pink as they develop. In this state the sepals of the flowers are not easily visualized. In Figure 2B, 53 DAI flower state is shown. Pink bracts were observed with the sepals and petals inside which surrounded the other organs of the flower. By reviewing 53 DAI flowers it was possible to identify the absence of sepals inside some bracts (Fig. 2C). By reviewing the bracts, it was possible to identify that within some of them there were no flower buds. When the inflorescence was observed in greater detail and all the bracts were removed the absence of floral organs was confirmed, so complete flower was not expeted to develop in that site (Fig. 2D, black circle). In this same figure, on another site, three sepals that will form a complete flower can be distinguished, in the center of these sepals violet petals are observed, close to emerging.

In a flower with the state of figure $2 \mathrm{E}$ the basal flowers were fully formed and their parts were easily observed: the open violet petals, the stigma and the anthers were visible. The development and growth of the flowers in the inflorescence occured consecutively, in the form of an ascending spiral, from the basal flowers; therefore, basal flowers are older than the upper ones. After 70 DAI (Fig. 2F), flowers at the top of the inflorescence were completely formed, and the basal flowers withered, due to the self-incompatibility. Bracts, sepals, and ovary that remain in the basal part of the inflorescence begin with the formation of the fruit by parthenocarpy; process in which a fruit is produced without the fertilization of the ovules by the pollen grains. The flowering stage ended at 83 DAI, when flower petals are wilted (Fig. 2G). The bracts that had no flower remained in the same stage during the hole flowering period (Fig. 2G, signaling). Figure $2 \mathrm{H}$ shows a $120 \mathrm{DAI}$ fruit that is growing.

Subsequently, in the fruit filling stage, the absence of fruits can be clearly observed at the bract sites where the flowers did not form (Fig. 3A). In some fruits, a small protuberance could be observed in the place where the flower did not form, possibly formed by the pressure exerted by the growth of the adjacent flowers on this space. However, this bulge is poorly developed and leads to the expression of deformation. Physiological disorder has been found to occur and does not generate malformation of the fruit when one or two contiguous horizontal flowers are missing (Fig. 3B, red circle). This "beneficial" symptom was observed in $69 \%$ of the sampled plants. In the case of the absence of three or more contiguous flowers, the deformation is visible.

Monitoring was carried out in the 800 plants monitored after the appearance of the floral bud $96 \%$ had mild (absence of 2 flowers) to severe (no flower was formed) deformity symptoms (Tab. 3 and Fig. 4). 

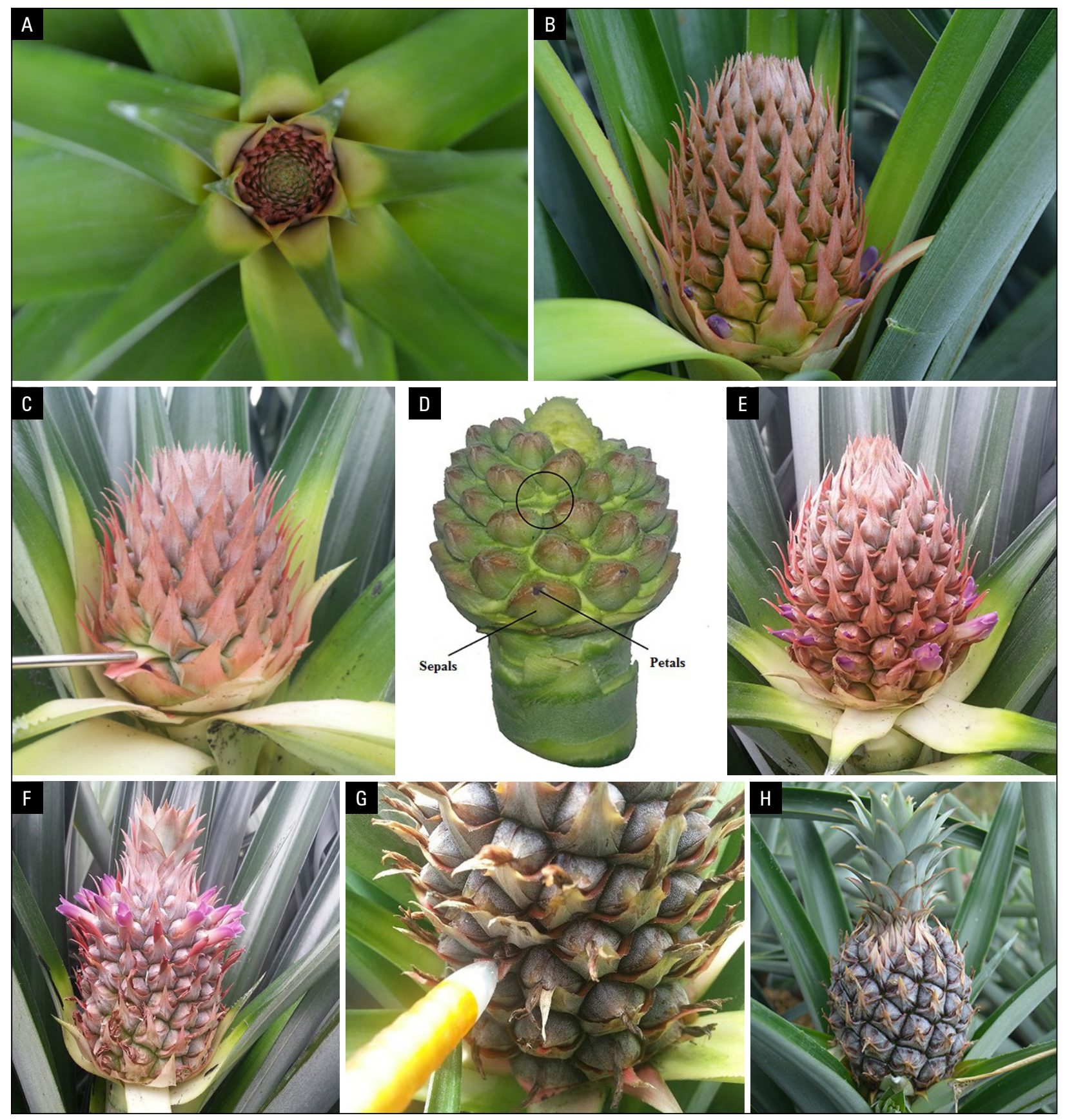

Figure 2. Visual monitoring of the $A$. comosus flower development to identify deformation onset in a fruit section. A) Flower bud; B) inflorescence aged 53 DAl; C) absence of sepals; D) identification of the deformity in inflorescence aged 53 DAI, in the black circle the absence of the flower bud is observed; E) inflorescence of $66 \mathrm{DDI}$ age; F) formation of the flowers of the upper part of the inflorescence; G) completion of flowering and wilting of petals; $H$ ) fruit growth. Photos: Y. Gómez.

\section{Table 3. Plants with deformity in a fruit section}

\begin{tabular}{|c|c|c|c|}
\hline Number of plants evaluated & Buds with the physiological disorder & Complete buds & $\%$ of plants with the physiological disorder \\
\hline 800 & 766 & 34 & $96 \%$ \\
\hline
\end{tabular}



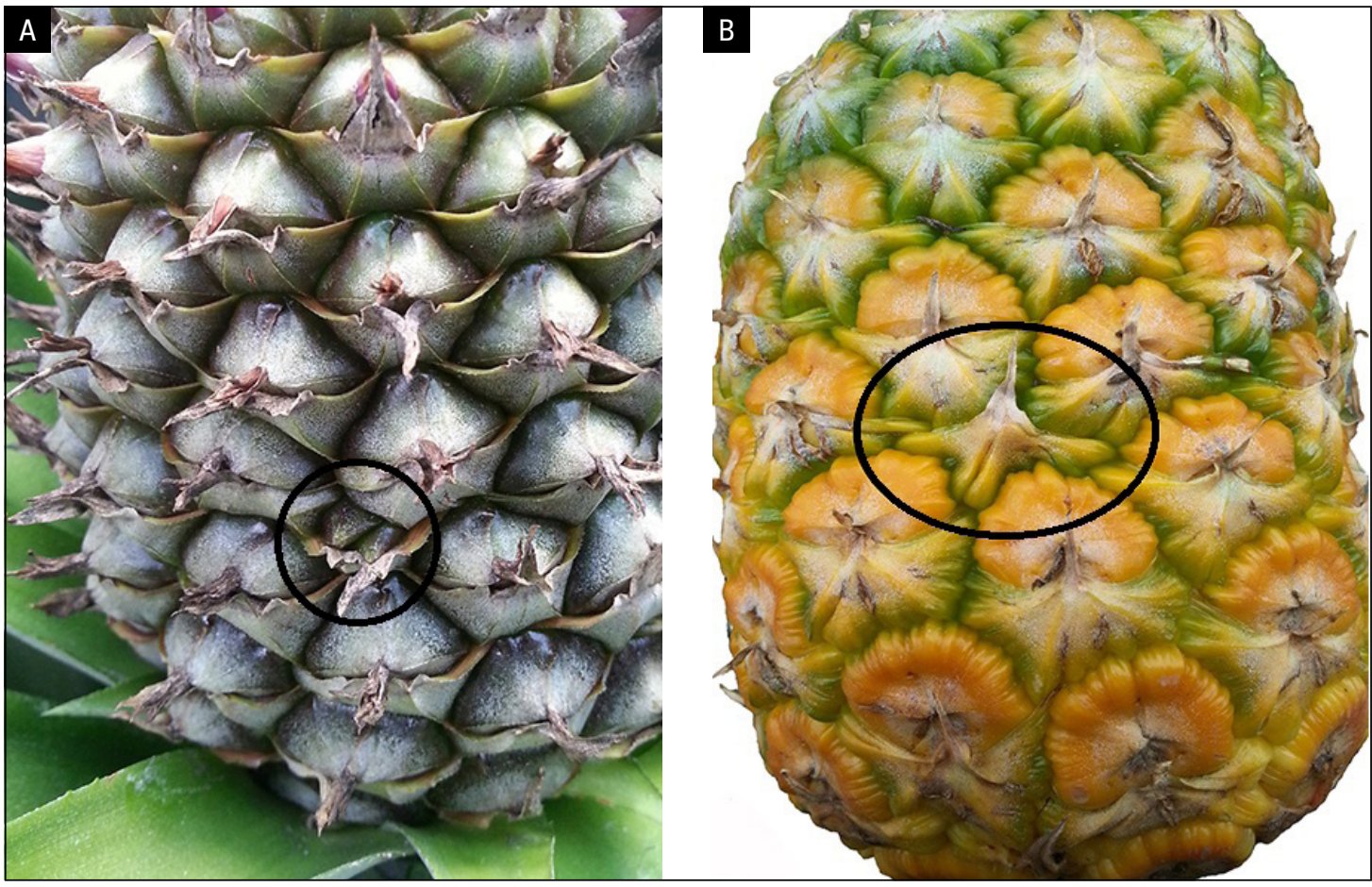

Figure 3. Symptoms of the physiological disorder. A) Bracts without a flower during fruit filling; B) pineapple fruit with the absence of one flower; the symptom is masked. Photos: Y. Gómez.

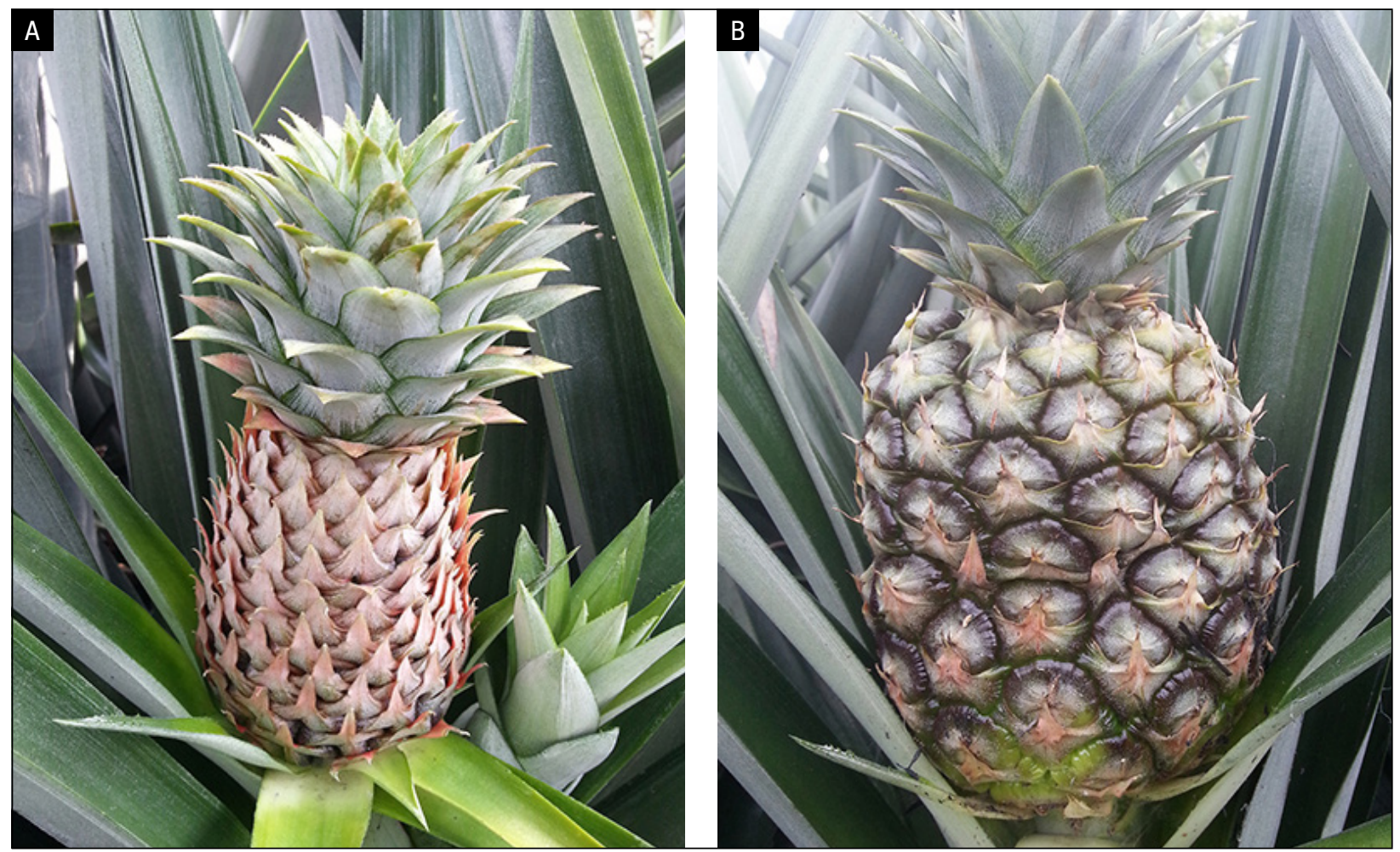

Figure 4. Presence of the deformity in pineapple MD2 fruits. A) Severe symptomatology; B) mild symptomatology. Photos: Y. Gómez. 


\section{A}

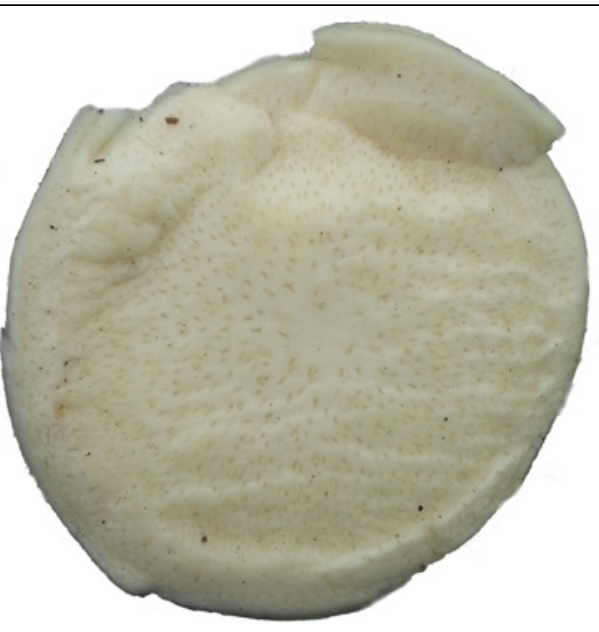

C

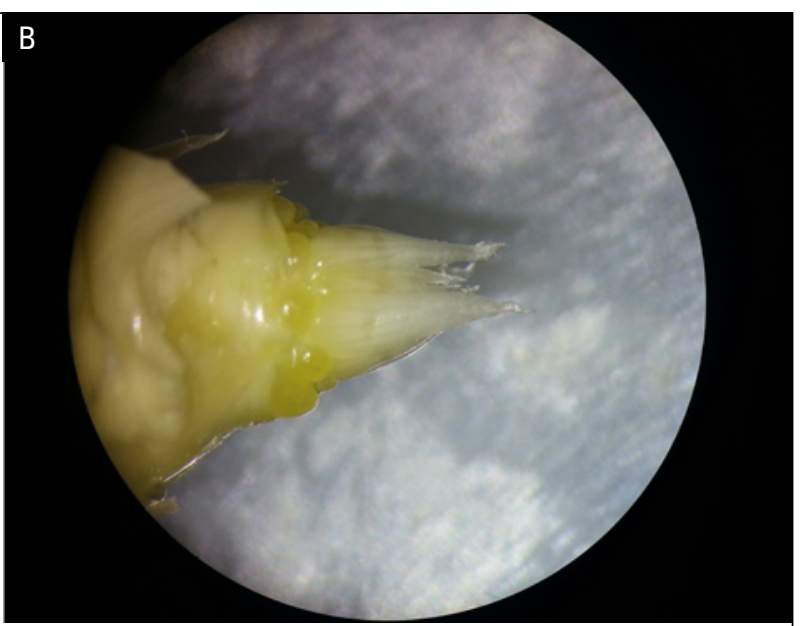

D

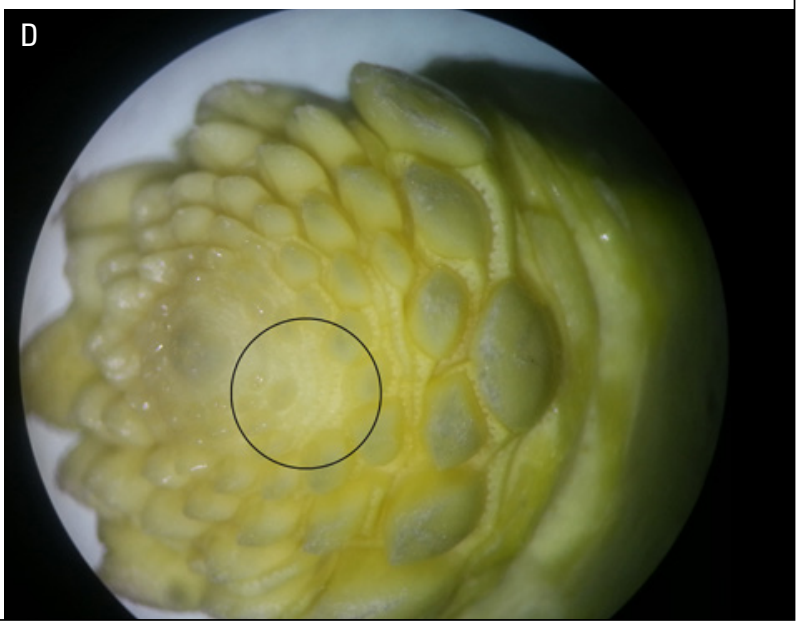

Figure 5. Formation process and visualization of the deformity in the pineapple inflorescence. A) Floral primordium in the first week after induction (WAI); B) floral primordium in the second WAl; C) floral primordium in the third WAI; D) floral primordium in the fourth WAI with the deformity clearly visible (black circle). Photos: Y. Gómez.

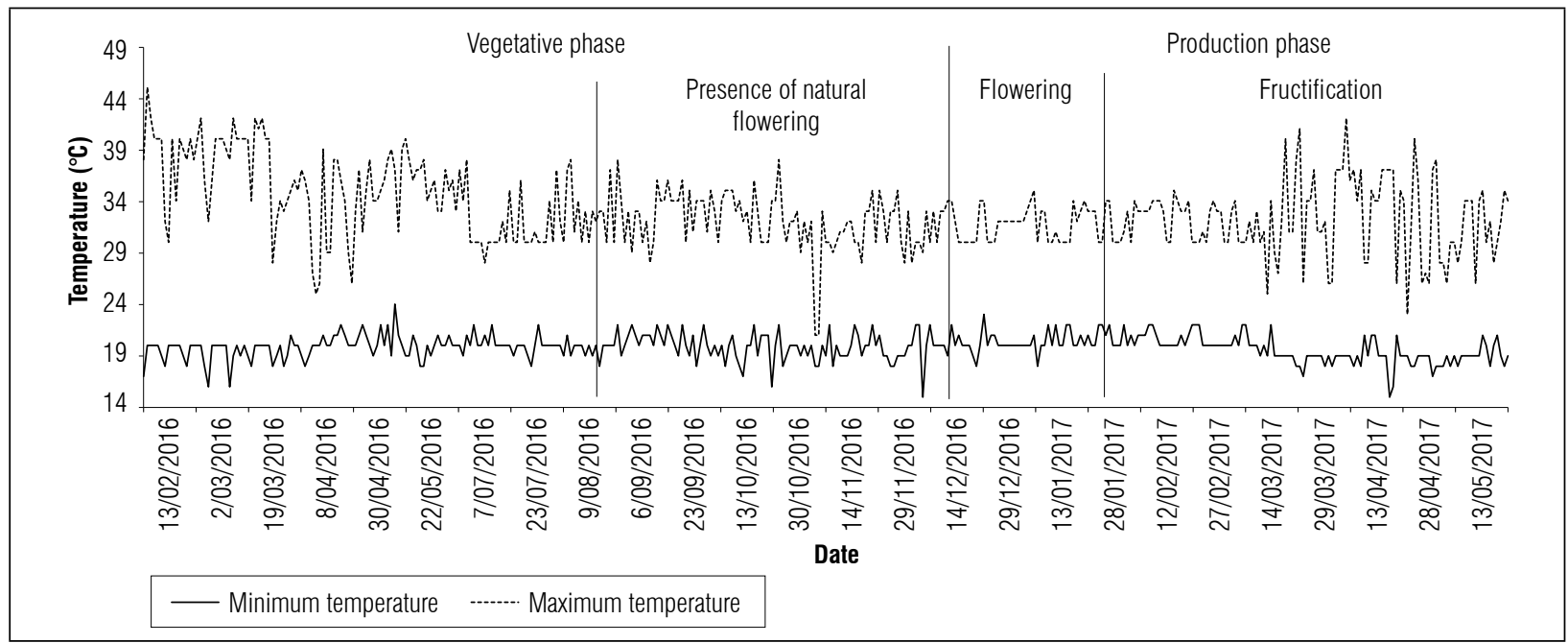

Figure 6. Maximum and minimum daily temperature behavior during the pineapple crop cycle on farm 1. 


\section{Floral primordia monitoring}

First week after induction, no floral meristems were observed (Fig. 5A). In the second week, the meristems of the individual flowers were already formed in the basal part. Then, inflorescence formation began (Fig. $5 \mathrm{~B})$. In the third week, inflorescence had a diameter of $5 \mathrm{~mm}$; further, the meristems of the central section were formed. In this state, it was not possible to observe whether the physiological disorder occurred or not (Fig. 5C). Meristems of the upper part of the inflorescence were visible in the fourth week after induction (Fig. 5D). Up to 13 meristems were observed per spiral from the base to the top of the inflorescence. Also leaf buds from the vegetative seed differentiated and were going to form fruit crown. In figure 5D (black circle), it was possible to detail that some floral meristems were missing, and this created a deformity in the middle and upper part of the fruit. From the fourth week after induction all the flower buds have formed and the spaces where they are absent are observed.

\section{Environmental temperature monitoring}

The maximum average temperature recorded in farm 1 was $32.0^{\circ} \mathrm{C}$ and the minimum average temperature was $19.7^{\circ} \mathrm{C}$. (Fig. 6). On October 26, before floral induction, plants with flower buds formed inflorescences and fruits close to harvest were observed; the low nocturnal temperatures could have caused this heterogeneity of ages in the fruit that occurred during plant development. This result agrees to what was reported by Friend and Lydon (1979) who stated that night temperatures of $20^{\circ} \mathrm{C}$ accelerate the natural flowering process in pineapple. In this study, the moment in which natural flowering possibly occurred (August 2016), temperatures equal to and below $20^{\circ} \mathrm{C}$ were recorded, as shown in figure 6.

Nonetheless, temperature should not be considered as the only factors linked to natural flowering induction; physiological state, nutritional status, and agronomic management (Cunha, 2005), as well as seed age and size homogeneity, and having undergone a pre-induction process from the induction of the mother plant, are also associated to this process.

Flowering period (from flower induction to the upper inflorescence flowers falling) in the first temperature evaluation on farm 1 was recorded from December 14, 2016, to January 25, 2017 (Fig. 7). A maximum temperature of $35^{\circ} \mathrm{C}$ and a minimum of $18^{\circ} \mathrm{C}$ were registered. As can be seen in, the first week after induction, i.e., December 14 to 21, 2016, the maximum temperatures, increased from $30^{\circ} \mathrm{C}$ and to up to $34^{\circ} \mathrm{C}$ in the second week after induction (December 22 to 29, 2016) (Fig. 7). In the third week (December 30, 2016 , to January 5,2017 ), a temperature of $35^{\circ} \mathrm{C}$ was recorded, and then, in the $4^{\text {th }}$ week (January 6 to 13, 2017), a temperature of $34^{\circ} \mathrm{C}$ was also registered. Furthermore, $96 \%$ (Tab. 3) of the sampled fruits were found to have the deformity. This malformation was observed in all sections of the fruit, from the basal to the upper flowers.

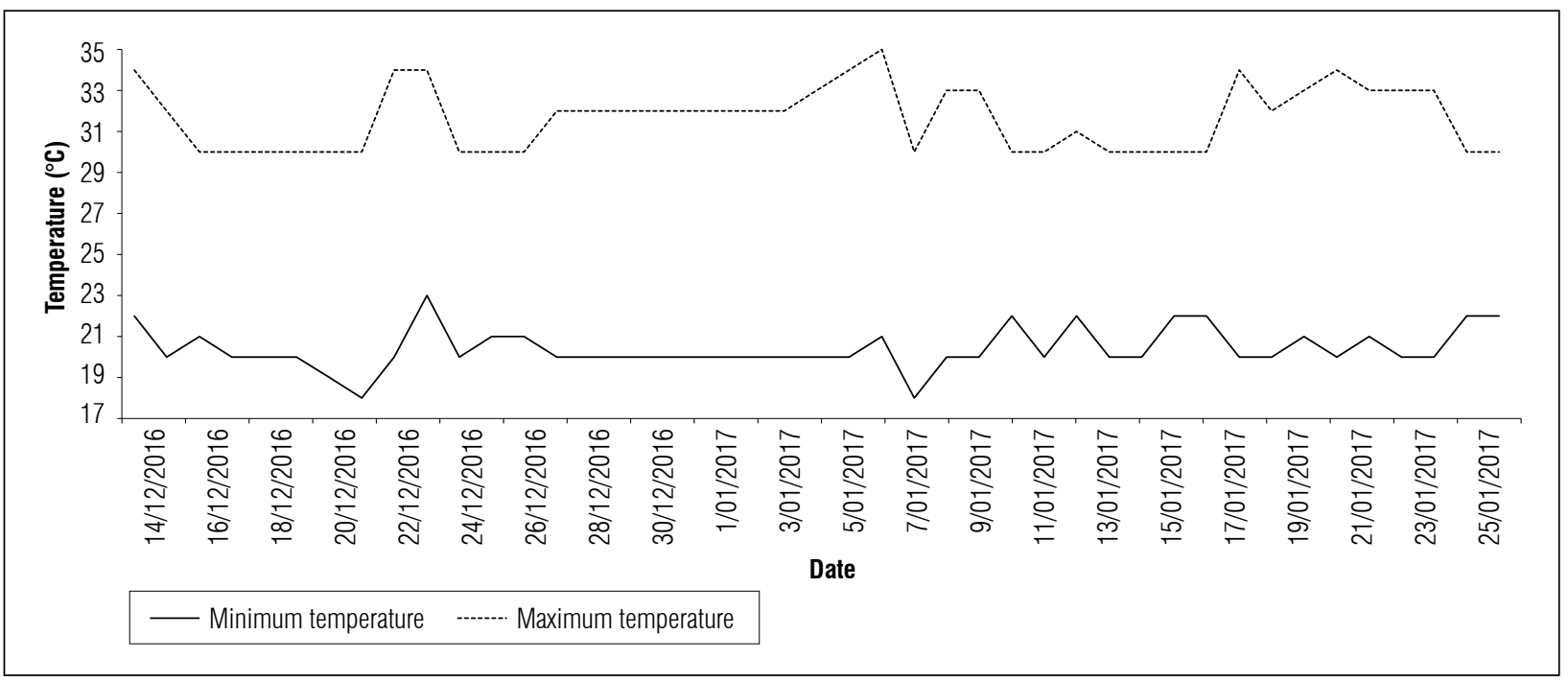

Figure 7. Maximum and minimum daily temperature behavior during flowering on farm 1. 
A second evaluation to measure temperature inside the crop was carried out, aiming to achieve a better interpretation of temperature effect. Second evaluation took place on farm 2, from August 12 to September 10, 2017; during the first four WAI, floral meristem differentiation was visible. Figure 8 shows temperature behavior durin this period. High temperatures reached a maximum of $58.5^{\circ} \mathrm{C}$ and a minimum of $15.5^{\circ} \mathrm{C}$. These temperatures could be affecting flower bud development.

Previous research on various crops have shown this, Wang et al. (2018) found that in tomato (Solanum lycopersicum L.), low moisture content and high-temperature conditions decreased pollen grains viability and size and hence reduced fruiting. Furthermore, temperatures outside the optimal range for different species, lead to physiological disorders in male and female reproductive systems (Hedhly, 2011). In cherimoya (Annona cherimola Mill.), temperatures above $25^{\circ} \mathrm{C}$ reduce pollen germination, and impairs fertilization of some flowers of the inflorescence and caused fruit malformation (Higuchi et al., 1998). In the case of mango, low temperatures during flowering increase the number of embryo abortions during development (Sukhvibul et al., 2005), and for other fruit tree species, high temperatures have been found to delay flowering (Diggle and Mulder, 2019). It has also been observed that high temperatures could be affecting gene expression. Effects of this type have been reported in Populus; this genus includes trees from the northern temperate and cold zones commonly known as poplar or aspen, where high temperatures affect the expression of the PtFT1 gene, preventing the formation of the reproductive meristem (Diggle and Mulder, 2019). In cauliflower, day/ night temperatures above $27 / 22^{\circ} \mathrm{C}$ affect the expression of the genes responsible for the flowering time (Sun et al., 2018).

Highest temperatures $\left(58.0,58.5\right.$, and $59.0^{\circ} \mathrm{C}$ ) occurred between third and fourth WAI, period in which flowers of central and upper part of the fruit were formed. This is the reason why it is thought that this temperature anomaly at the experimental site could be affecting the process of flower formation, promoting deformation.

Sample from 150 DAI, which were close to harvesting time, $78 \%$ of the fruits presented a deformity caused by the physiological disorder. Of these malformed fruits, $43 \%$ showed marked symptoms of damage, which were sufficiently severe to imply that they would not be acceptable for export. The presence of the deformity showed no obvious systematic occurrence with some areas showing severe symptoms in some fruits whilst their neighbors were good physicals conditions.

Pineapple fruit samples of the same age that had the same number of fruits per inflorescence were used to verify the expression of the physiological disorder on this period. Symptoms were in different sectors throughout the fruit, from the basal part to the top of the fruit, that is, the deformity was expressed in the flowers at different times during the fruits formation. Any maximum temperature event from the beginning of the formation of the buds could have affected the floral development.

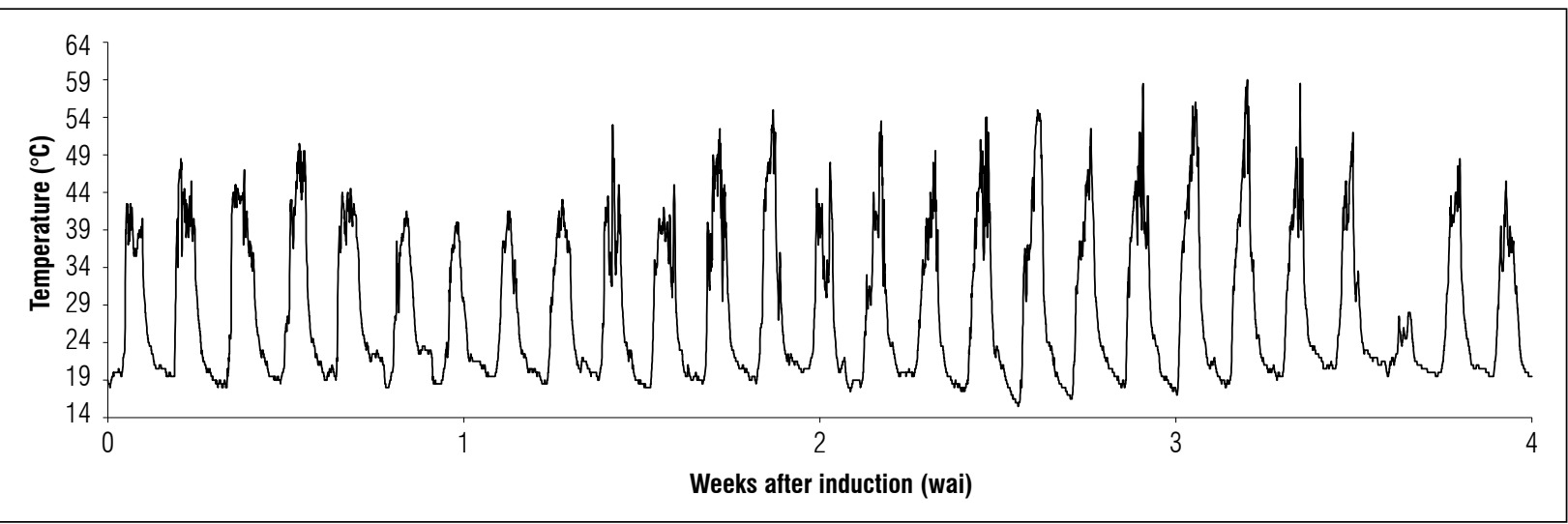

Figure 8. Temperature behavior during four weeks after induction (WAI) in the second evaluation session on farm 2. 


\section{An approach to the effect of nutrition on the physiological disorder}

To verify the effect of environmental and management factors -ruling out irrigation- flowering and nutrition induction processes were monitored. Flowering induction labor was monitored, verifying that a single solution-hormone mixture was prepared for the entire crop; the same dose was used for each plant, avoiding wind drift and evaporation. This rigor allows ruling out an effect of the induction factor.

Nutrient analyses of tissue from affected inflorescences with the physiological disorder and of the unaffected ones are presented in table $4 . \mathrm{N}, \mathrm{P}, \mathrm{Mg}, \mathrm{K}$, $\mathrm{Ca}, \mathrm{Na}, \mathrm{S}, \mathrm{Fe}$, and $\mathrm{B}$ contents are similar between the samples. Therefore, it is assumed that these elements the content was not the problem that triggered the disorder. However, the $\mathrm{Cu}, \mathrm{Mn}$ and $\mathrm{Zn}$ contents were high in the samples of inflorescences affected with the physiological disorder; therefore, it was necessary to verify the sources of nutrients in the crop. The fertilization plan was reviewed, and it was observed that $\mathrm{Cu}$ was not added, and $\mathrm{Mn}$ and $\mathrm{Zn}$ are applied in low quantities, therefore, fertilization applied by the farmer was discarded. Similarly, soil analysis was studied, and a high content of $\mathrm{Ca}, \mathrm{Mg}, \mathrm{Fe}, \mathrm{Cu}, \mathrm{Mn}$ and $\mathrm{Zn}$ was found. $\mathrm{Cu}, \mathrm{Mn}$ and $\mathrm{Zn}$ high levels in the soil were also high in affected inflorescences, for this reason, that toxicity of these elements in the soil could be associated with the physiological disorder in the plant preventing the complete formation of the inflorescence and later of the fruit.
Other studies report that the nutrient content in the plant alters flowering (Marín et al., 2011; Lin et al., 2019; Ye et al., 2019). In the case of rice (Oryza sativa L.), low nitrogen content in the plant accelerates flowering time up to $3 \mathrm{~d}$ compared to nitrogenprovided plants (Ye et al., 2019). The same happens with Arabidopsis thaliana, where low nitrate content accelerated flowering (Marín et al., 2011). Another mineral that alters flowering is potassium. It has been observed that in rice, as the $\mathrm{K}$ content in the plant increases, flowering accelerates and occurs in less time compared to plants with low content of this element (Ye et al., 2019). In this study, there were no differences in the content of $\mathrm{N}$ and $\mathrm{K}$ in buds with and without the physiological disorder; however, the difference in the contents of other nutrients and the high contents in the soil allowed generating a new hypothesis regarding the problems in the formation of the pineapple flower. However, it is caused by flowers malformations beyond the scope of this study to verify the reason and, consequently, to discover the reason for the existence of healthy plants free of this physiological disorder while growing in the same soil and under the same edaphoclimatic conditions during the long cultivation cycle. These unsolved questions deserve further investigation.

\section{CONCLUSIONS}

Physiological disorder expressed as a deformity on the pineapple fruit (Spanish mal de cintura), cultivated in the agroclimatic conditions of the flat areas

Table 4. Comparison of the nutrients found in flower buds with and without the physiological disorder.

\begin{tabular}{|l|c|c|c|}
\hline \multicolumn{1}{|c|}{ Element } & Soil & Bud without the physiological disorder & Bud with the physiological disorder \\
\hline Nitrogen (N) & $0.05 \%$ & $2.93 \%$ & $2.85 \%$ \\
\hline Phosphorous (P) & $0.78 \mathrm{mg} \mathrm{kg}^{-1}$ & $0.13 \%$ & $0.10 \%$ \\
\hline Potassium (K) & $0.48 \mathrm{cmol} \mathrm{kg}^{-1}$ & $1.34 \%$ & $1.43 \%$ \\
\hline Calcium (Ca) & $13.20 \mathrm{cmol} \mathrm{kg}^{-1}$ & $2.61 \%$ & $2.58 \%$ \\
\hline Magnesium (Mg) & $4.70 \mathrm{cmol} \mathrm{kg}^{-1}$ & $0.31 \%$ & $0.21 \%$ \\
\hline Sodium (Na) & $0.37 \mathrm{cmol} \mathrm{kg}^{-1}$ & $<0.0033 \%$ & $<0.0033 \%$ \\
\hline Sulfur (S) & $24 \mathrm{mg} \mathrm{kg}^{-1}$ & $0.21 \%$ & $0.22 \%$ \\
\hline Iron (Fe) & $315 \mathrm{mg} \mathrm{kg}^{-1}$ & $123.04 \mathrm{mg} \mathrm{kg}^{-1}$ & $122.76 \mathrm{mg} \mathrm{kg}^{-1}$ \\
\hline Copper (Cu) & $8.2 \mathrm{mg} \mathrm{kg}^{-1}$ & $3.40 \mathrm{mg} \mathrm{kg}^{-1}$ & $5.60 \mathrm{mg} \mathrm{kg}^{-1}$ \\
\hline Manganese (Mn) & $36 \mathrm{mg} \mathrm{kg}^{-1}$ & $18.50 \mathrm{mg} \mathrm{kg}^{-1}$ & $38.20 \mathrm{mg} \mathrm{kg}^{-1}$ \\
\hline Zinc (Zn) & $4.4 \mathrm{mg} \mathrm{kg}^{-1}$ & $20.75 \mathrm{mg} \mathrm{kg}^{-1}$ & $26.72 \mathrm{mg} \mathrm{kg}^{-1}$ \\
\hline Boron (B) & $0.34 \mathrm{mg} \mathrm{kg}^{-1}$ & $19.76 \mathrm{mg} \mathrm{kg}^{-1}$ & $19.59 \mathrm{mg} \mathrm{kg}^{-1}$ \\
\hline
\end{tabular}


of the department of Valle del Cauca, Colombia, is generated in an early state of the inflorescence formation and is expressed from the fourth week after induction. This deformity represents a physical problem that generates a rejection in its commercialization, as these considered third category fruits. This problem causes the loss of close to $30 \%$ of the exporttype production in some farms in the Valle del Cauca department.

Crop management, rainfall regime, type of soil, and poor drainage led to high water content in the soil. This condition and the expression of the physiological disorder on $96 \%$ of the fruits evaluated, lead to the rejection of the hypothesis that the deformity disorder has its origin in a state of stress of the plant due to water deficit.

The second hypothesis that arose from an early rejection of the first one was that a temperature anomaly during flower formation could adversely affect the process. This is the most likely hypothesis at this level of the research, verified by the occurrence of maximum temperatures in the period of flower formation. The anomalies of the temperature could be affecting the gene expression for the formation of the flower, with the consequent abortion of individual flowers. However, an analysis of gene expression on pineapple flowering will be necessary to support this hypothesis fully.

Furthermore, it is possible that copper, manganese, and zinc excess in the soil has generated some toxicity in the plant and is enhancing the expression of the physiological disorder. These elements excess in the soil could be affecting the crop in general; however, the decisive effect could come from the application of foliar fertilization. The non-rigorous application with the appropriate dose, with a not well-calibrated application nozzle, could deliver an overdose of these elements. However, a controlled evaluation with these elements will be necessary to generate a conclusive result.

This work is only a starting point for the assessment of this important problem that generates appreciable losses in pineapple export production. Evaluations under controlled conditions and others directly at the cropping site in different environments will be necessary, measuring all associated climatic factors, as well as an evaluation of the genetic factor.

\section{ACKNOWLEDGMENTS}

The authors wish to thank the pineapple producer Mr. Luis Miguel Cabal, for his exceptional logistical and financial support to this study. Also, to Colombian Agricultura Research Corporation (Agrosavia), C.I. Palmira, for the scientific guidance and support in the publication of this work. Furthermore, to Universidad Nacional de Colombia, Palmira Campus, because this study is an undergraduate agronomy thesis developed a student this institution. Dr. Takumasa Kondo (Agrosavia) kindly checked the English text.

Conflict of interests: The manuscript was prepared and reviewed with the participation of the authors, who declare that there exists no conflict of interest that puts at risk the validity of the presented results.

\section{BIBLIOGRAPHIC REFERENCES}

Bartholomew, D.P. and S.B. Kadzimin. 1977. Pineapple. pp. 113-156. In: Alvim, P.T. and T.T. Kozlowski (eds.). Ecophysiology of tropical crops. Academic Press, London. Doi: 10.1016/B978-0-12-055650-2.50010-1

Cabal, L.M. 2014. Manual del sistema de gestión de calidad. CI Elixir SAS, Guadalajara de Buga, Colombia.

Carr, M.K. 2012. The water relations and irrigation requirements of pineapple (Ananas comosus var. comosus): A Review. Exp. Agric. 48(4), 488-501. Doi: 10.1017/ S0014479712000385

Codex Alimentarius. 2011. Standard for pineapples CXS 182-1993. FAO; WHO, Rome.

Crane, J. 2019. Pineapple growing in the Florida Home landscape. Publ HS7 original publication 1975. In: Horticultural Sciences Department, UF/IFAS Extension, https://edis.ifas.ufl.edu; consulted: April, 2019.

Cunha, G.A.P. 2005. Applied aspects of pineapple flowering. Bragantia 64(4), 499-516. Doi: 10.1590/ S0006-87052005000400001

Diggle, P. and C. Mulder. 2019. Diverse developmental responses to warming temperatures underlie changes in flowering phenologies. Integr. Comp. Biol. 59(3), 559570. Doi: $10.1093 /$ icb/icz076

Friend, D.J.C. and J. Lydon. 1979. Effects of daylength on flowering, growth, and CAM of pineapple (Ananas comosus [L.] Merrill). Bot. Gaz. 140(3), 280-283. Doi: $10.1086 / 337086$

Hedhly, A. 2011. Sensitivity of flowering plant gametophytes to temperature fluctuations. Environ. Exp. Bot. 74, 9-16. Doi: 10.1016/j.envexpbot.2011.03.016 
Higuchi, H., N. Utsunomiya, and T. Sakuratani. 1998. High temperature effects on cherimoya fruit set, growth and development under greenhouse conditions. Sci. Hortic. 77(1-2), 23-31. Doi: 10.1016/ S0304-4238(98)00160-5

Kennelly, M., J. O'Mara, C. Rivard, G. Miller, and D. Smith. 2012. Introduction to abiotic disorders in plants. In: The Plant Health Instructor. American Phytopathological Society-APS. Doi: 10.1094/PHI-I-2012-10-29-01

Lin, J.-A., H. Susilo, J.-Y. Lei, and Y.-C.A. Chang. 2019. Effects of fertilizer nitrogen shortly before forcing through flowering on carbon-nitrogen composition and flowering of Phalaenopsis. Sci. Hortic. 252, 61-70. Doi: $10.1016 /$ j.scienta.2019.02.006

Maia, V.M., R.F. Pegoraro, I. Aspiazú, F.S. Oliveira, and D.A.C. Nobre. 2020. Diagnosis and management of nutrient constraints in pineapple. pp. 739-760. In: Srivastava, A.K. and C. Hu (eds.). Fruit crops: Diagnosis and management of nutrient constraints. Elsevier, Amsterdam. pp. 739-760. Doi: 10.1016/ B978-0-12-818732-6.00050-2

Marín, I.C., I. Loef, L. Bartetzko, I. Searle, G. Coupland, M. Stitt, and D. Osuna. 2011. Nitrate regulates floral induction in Arabidopsis, acting independently of light, gibberellin and autonomous pathways. Planta 233(3), 539-552. Doi: 10.1007/s00425-010-1316-5
Sukhvibul, N., A.W. Whiley, and M.K. Smith. 2005. Effect of temperature on seed and fruit development in three mango (Mangifera indica L.) cultivars. Sci. Hortic. 105(4), 467-474. Doi: 10.1016/j.scienta.2005.02.007

Sun, X., J. Bucher, Y. Ji, A.D. van Dijk, R.G.H. Immink, and G. Bonnema. 2018. Effect of ambient temperature fluctuation on the timing of the transition to the generative stage in cauliflower. Environ. Exp. Bot. 155, 742-750. Doi: 10.1016/j.envexpbot.2018.06.013

USDA, United States Department of Agriculture. 1999. Guía para la evaluación de la calidad y salud del suelo. Washington, DC.

Vásquez, H.D., R. Saavedra and S.H. Saavedra. 2012. Piña (Ananas comosus L. Merr.). pp. 776-801. In: Fischer, G. (ed.). Manual para el cultivo de frutales en el trópico. Produmedios, Bogota.

Wang, S.S., Y.L. Li, and X.Z. Wen. 2018. Effect of increasing humidity on flowering, fruit-setting and pollen characteristics of tomato under heat stress. Acta Hortic. 1227, 305-312 Doi: 10.17660/ActaHortic.2018.1227.37

Ye, T., Y. Li, J. Zhang, W. Hou, W. Zhou, J. Lu, Y.Xing, and X. Li. 2019. Nitrogen, phosphorus, and potassium fertilization affects the flowering time of rice (Oryza sativa L.). Glob. Ecol. Conserv. 20, e00753. Doi: 10.1016/j. gecco.2019.e00753 